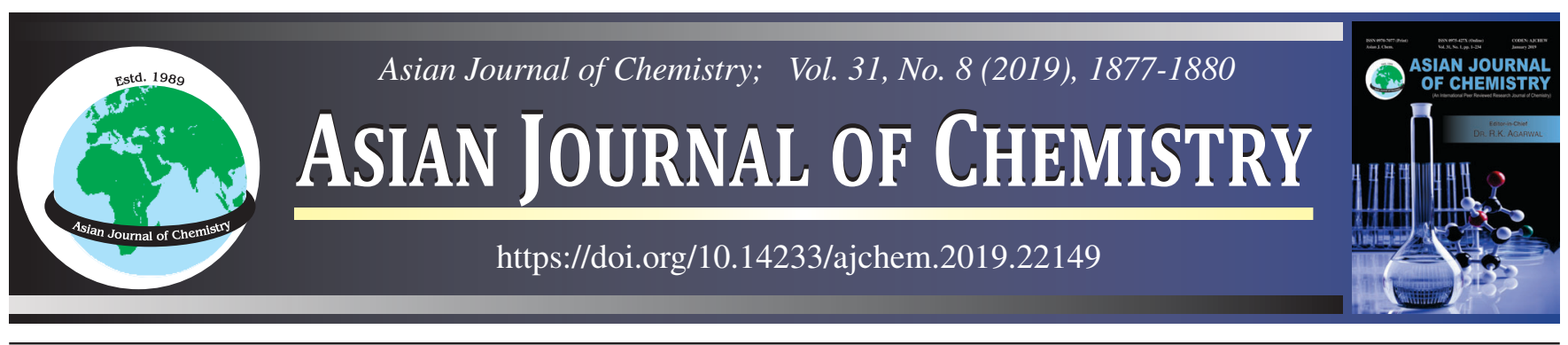

\title{
Synthesis and X-Ray Crystal Structure of 1,1'-Bis(diphenyphosphino)ferrocene Supported $\mathrm{CuSCF}_{3}$ Complex
}

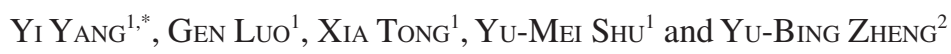

${ }^{1}$ College of Chemistry and Environmental Engineering, Sichuan University of Science and Engineering, Zigong 643000, P.R. China

${ }^{2}$ Shandong Jinjing Biological Technology Co. Ltd., Weifang 261313, P.R. China

*Corresponding author: Fax: + 86813 5505606; Tel: +86 813 5505601; E-mail: yangyiyoung@163.com

Received: 24 April 2019;

Accepted: 21 May 2019;

Published online: 28 June 2019;

AJC-19469

We report herein the synthesis of $\mathrm{CuSCF}_{3}$ complex supported by 1,1'-bis(diphenyphosphino)ferrocene via deoxygenative reduction of Langlois reagent $\left(\mathrm{CF}_{3} \mathrm{SO}_{2} \mathrm{Na}\right)$. This cuprous complex $\left[(\mathrm{dppf}) \mathrm{Cu}\left(\mathrm{SCF}_{3}\right)\right]$ was fully characterized by elemental analysis and ${ }^{1} \mathrm{H}\left({ }^{13} \mathrm{C}\right.$, ${ }^{19} \mathrm{~F}$,

$\left.{ }^{31} \mathrm{P}\right) \mathrm{NMR}$ spectra. In addition, the molecular structure of $\left[(\mathrm{dppf}) \mathrm{Cu}\left(\mathrm{SCF}_{3}\right)\right]$ was established by X-ray crystallography. The crystal of compound 1 crystallizes in monoclinic, space group $\mathrm{P} 2{ }_{1} / \mathrm{n}$ with $\mathrm{a}=11.4366(9), \mathrm{b}=19.1340(16), \mathrm{c}=14.0625(11) \AA, \mathrm{V}=3072.62(2) \AA^{3}$, $\mathrm{Z}=4, \mathrm{Z}^{\prime}=0, \mathrm{C}_{35} \mathrm{H}_{28} \mathrm{CuF}_{3} \mathrm{FeP}_{2} \mathrm{~S}, \mathrm{Mr}=719.00$ and $\mathrm{R}$-factor $=3.69$. The short contacts between the two fluorine atoms of $\mathrm{CF}_{3} \mathrm{~S}$ moiety and aromatic hydrogen of $\mathrm{Cp} /(\mathrm{Ph})$ rings were observed with leaving the sterically-congested fluorine untouched which highly resembled to the sibling $\left[\left(\mathrm{PPh}_{3}\right)_{2} \mathrm{CuSCF}_{3}\right]$. These interesting secondary interactions in the crystal lattice were explained by the electrostatic forces in terms of the strong dipole of $\mathrm{C}-\mathrm{F}$ bonds.

Keywords: Copper, 1,1'-Bis(diphenyphosphino)ferrocene, Trifluoromethylthio group, Crystal structure.

\section{INTRODUCTION}

Over the past few decades, the fluorine and fluorine-containing group ligated transition metal coordination compounds have received substantial attentions within the synthetic communities due to their importance in the discovery of unconventional structural patterns and the guidance for innovation of direct fluorination or fluoroalkylation reaction methodologies $[1,2]$. Among the various reported $\left[\mathrm{L}_{\mathrm{n}} \mathrm{MR}_{\mathrm{f}}\right]$ complexes $(\mathrm{M}=$ transition metals; $\mathrm{R}_{\mathrm{f}}=$ fluorine or fluorine-containing groups), the trifluoromethylthiolated coordination compounds $\left[\mathrm{L}_{\mathrm{n}} \mathrm{M}\left(\mathrm{SCF}_{3}\right)_{\mathrm{m}}\right]$ are well prized and recognized as versatile intermediates for the synthesis of $\mathrm{CF}_{3} \mathrm{~S}$-organics [3-5]. For example, Weng group has developed a series of $\left[\mathrm{L}_{n} \mathrm{Cu}\left(\mathrm{SCF}_{3}\right)\right]$ complexes $(\mathrm{L}=$ bipyridine, phen and $\mathrm{PPh}_{3}$, Fig. 1) as efficient nucleophilic trifluoromethylthiolating reagents for several types of organohalides including aryl halides [6], benzylic halides [7] and allylic halides [8,9]. Particularly, unlike the [(bipy) $\mathrm{Cu}\left(\mathrm{SCF}_{3}\right)$ ] complex [6], $\left[\left(\mathrm{Ph}_{3} \mathrm{P}\right)_{2} \mathrm{Cu}\left(\mathrm{SCF}_{3}\right)\right]$ complex prepared from the simple and inexpensive monodentate triphenylphosphine was proved to be effective in the coupling with allylic bromides other than aryl bromides [9]. It is evident that the selection of supporting ligands $(\mathrm{L})$ has profound influences on the reactivities of these $\mathrm{CuSCF}_{3}$ species and the structural characters especially the crystal structural information is crucial for elucidating the structure/reactivity relationships.

In this context, the further exploration of other types of elaborated phosphine ligand supported trifluoromethylthiolated coordination compounds is highly intriguing and desirable [10]. Herein, we report the synthesis of $\left[(\mathrm{dppf}) \mathrm{Cu}\left(\mathrm{SCF}_{3}\right)\right]$ via deoxygenative reduction [11] and dppf ligand supporting strategy and make structural comparison studies between the $\mathrm{X}$-ray structure of $\left[(\mathrm{dppf}) \mathrm{Cu}\left(\mathrm{SCF}_{3}\right)\right]$ and $\left[\left(\mathrm{Ph}_{3} \mathrm{P}\right)_{2} \mathrm{Cu}\left(\mathrm{SCF}_{3}\right)\right]$ in order to obtain a better understanding of the primary bond parameters and secondary interactions within the crystal lattice which might be useful for guiding the further optimization of phosphineligated copper(I) trifluoromethylthiolate complexes [12,13].

\section{EXPERIMENTAL}

General information: All reactions were carried out using standard Schlenk and vacuum-line techniques under $\mathrm{N}_{2}$ atmosphere. Solvent $\mathrm{CH}_{3} \mathrm{CN}$ was distilled from calcium hydride.

This is an open access journal, and articles are distributed under the terms of the Attribution 4.0 International (CC BY 4.0) License. This license lets others distribute, remix, tweak, and build upon your work, even commercially, as long as they credit the author for the original creation. You must give appropriate credit, provide a link to the license, and indicate if changes were made. 


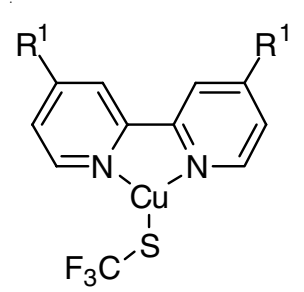

$\mathrm{R}=\mathrm{H}, \mathrm{Me}$ or ${ }^{\mathrm{t}} \mathrm{Bu}$

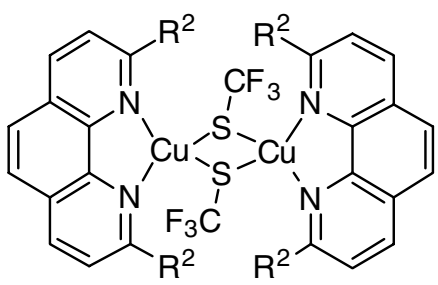

$\mathrm{R}=\mathrm{H}$ or $\mathrm{Me}$

(a) dinitrogen ligand coordinated $\mathrm{CuSCF}_{3}$ complex

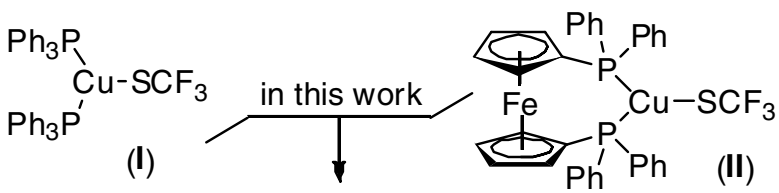

X-ray structure comparison

(b) monodentate $\mathrm{P}$-ligand coordinated $\mathrm{CuSCF}_{3}$ complex (c) bidentate $\mathrm{P}$-ligand coordinated $\mathrm{CuSCF}_{3}$ complex

Fig. 1. Representative $\left[\mathrm{L}_{\mathrm{n}} \mathrm{Cu}\left(\mathrm{SCF}_{3}\right)\right]$ complexes

Cuprous chloride $(\mathrm{CuCl})$, Langlois reagent $\left(\mathrm{CF}_{3} \mathrm{SO}_{2} \mathrm{Na}\right)$, triphenylphosphine $\left(\mathrm{Ph}_{3} \mathrm{P}\right), 1,1$ '-bis(diphenyphosphino)ferrocene (dppf) were commercially available and used as received. ${ }^{1} \mathrm{H},{ }^{13} \mathrm{C}$ and ${ }^{31} \mathrm{P}$ NMR were recorded on a Bruker AM-500 spectrometer. ${ }^{19} \mathrm{~F}$ NMR was recorded on another Bruker AM-500 spectrometer $\left(\mathrm{FCCl}_{3}\right.$ as outside standard and low field is positive). Chemical shifts (d) are reported in parts per million and coupling constants $(J)$ are in hertz. Crystallographic data were analyzed with Rigaku FCR Diffractimer.

Synthetic procedure: To a solution of $\mathrm{CF}_{3} \mathrm{SO}_{2} \mathrm{Na}(312$ $\mathrm{mg}, 2.0 \mathrm{mmol})$ and $\mathrm{CuCl}(198 \mathrm{mg}, 2.0 \mathrm{mmol})$ in acetonitrile $\left(8 \mathrm{~mL}\right.$, pre-cooled to $\left.-20^{\circ} \mathrm{C}\right)$ were added $\mathrm{Ph}_{3} \mathrm{P}(1048 \mathrm{mg}, 4.0$ $\mathrm{mmol}$ ). The reaction mixture was stirred under $\mathrm{N}_{2}$ atmosphere at room temperature for 3-5 h until completion. Then the reaction mixture was filtrated through PTFE filter to remove the insoluble salts and get a clear solution. This solution was frozen (approximately $-20^{\circ} \mathrm{C}$ ) for $24 \mathrm{~h}$ until the formation of crystalline $\mathrm{Ph}_{3} \mathrm{PO}$. The acetonitrile solution of $\mathrm{CuSCF}_{3}$ was collected by decanting to remove $\mathrm{Ph}_{3} \mathrm{PO}$ and cooled to $-20^{\circ} \mathrm{C}$ again. Then the solution of dppf (1109 mg, $2 \mathrm{mmol})$ in $\mathrm{CH}_{2} \mathrm{Cl}_{2}$ $(6.0 \mathrm{~mL})$ was added in drop-wise. The reaction solution was kept at the fridge (approximately $-20{ }^{\circ} \mathrm{C}$ ) for crystallization. The resulting crystals were collected by filtration and washed with cold acetonitrile $\left(3 \mathrm{~mL}\right.$, approximately $\left.-20{ }^{\circ} \mathrm{C}\right)$ and ether $(5 \mathrm{~mL})$ and dried under reduced pressure to afford the corresponding [(dppf) $\left.\mathrm{Cu}\left(\mathrm{SCF}_{3}\right)\right]$ complex (yellow colour powder, $992 \mathrm{mg}$, Yield $69 \%$ ).

Detection method: Single crystal of [(dppf) $\left.\mathrm{Cu}\left(\mathrm{SCF}_{3}\right)\right]$ compound suitable for $\mathrm{X}$-ray diffraction analysis can be grown from $\mathrm{CH}_{3} \mathrm{CN} /$ pentane solution. The crystal of compound (II) with dimensions of $0.221 \mathrm{~mm} \times 0.147 \mathrm{~mm} \times 0.101 \mathrm{~mm}$ was mounted on a Rigaku RAXIS-RAPID diffractometer equipped with a graphite-monochromated $\mathrm{MoK}_{\alpha}$ radiation $(\lambda=0.71073$ $\AA$ ) by using an w scan mode at 293(2) K. Absorption correction was performed by the CRYSTALCLEAR program [14]. The structure was solved by direct methods using the SHELXS97 program [15] and refined by full-matrix least-squares tech- niques on $\mathrm{F}^{2}$ data using SHELXL-97 [16]. The empirical absorption corrections were applied to all intensity data. All the hydrogen atoms were located by using the geometric method, with $\mathrm{d}(\mathrm{C}-\mathrm{H})=0.95-0.98 \AA$ and Uiso $(\mathrm{H})=1.2 \mathrm{Ueq}(\mathrm{C})$ or 1.5 Ueq (Cmethyl).

\section{RESULTS AND DISCUSSION}

The title compound II can be synthesized by two steps from the simple building block $\mathrm{CF}_{3} \mathrm{SO}_{2} \mathrm{Na}$ (named as Langlois reagent) according to our developed method. The deoxygenative reduction [17] of $\mathrm{CF}_{3} \mathrm{SO}_{2} \mathrm{Na}$ took place smoothly in the presence of triphenylphosphine and $\mathrm{CuCl}$ with employing acetonitrile as solvent. The resulting $\left[\mathrm{CuSCF}_{3}\right]$ complex was further coordinated by the bidentate-P ligand 1,1'-bis(diphenyphosphino)ferrocene (dppf) to afford the target complex $\left[(\mathrm{dppf}) \mathrm{Cu}\left(\mathrm{SCF}_{3}\right)\right](\mathbf{I I})$ in $69 \%$ yield (Scheme-I).

Compound II was an air-stable yellow metallic complex and fully characterized by ${ }^{1} \mathrm{H},{ }^{13} \mathrm{C},{ }^{19} \mathrm{~F}$ and ${ }^{31} \mathrm{P}$ NMR spectroscopies. Firstly, the ${ }^{1} \mathrm{H}$ and ${ }^{31} \mathrm{P}$ NMR spectra of compound II clearly indicated the successful binding of dppf ligand toward $\mathrm{Cu}$ core. Moreover, the ${ }^{19} \mathrm{~F}$ NMR spectra demonstrated the pattern of $\mathrm{CF}_{3} \mathrm{~S}$ motifs $(\delta-20.58 \mathrm{ppm})$ coordinating to $\mathrm{Cu}$ and ${ }^{13} \mathrm{C}$ NMR exhibited the spin-spin coupling between $\mathrm{F}(1)$ and $\mathrm{C}(1)$ with the coupling constant of $30.0 \mathrm{~Hz}(\delta 132.86 \mathrm{ppm})$.

Subsequently, a yellow single crystal of the $\left[(\mathrm{dppf}) \mathrm{Cu}\left(\mathrm{SCF}_{3}\right)\right]$ complex was grown from a $\mathrm{CH}_{3} \mathrm{CN} /$ pentane solution and the molecular structure was further characterized by X-ray diffraction analysis. ORTEP and crystal packing diagram of II are shown in Figs. 2 and 3, respectively and crystallographic and refinement parameters of the title compound II are listed in Table- 1 . The selected bond lengths and angles are given in Tables 2 and 3. The structure was solved by direct methods. Anisotropic displacement parameters were applied to all nonhydrogen atoms in full-matrix least-square refinements based on $\mathrm{F}^{2}$. The hydrogen atoms were set in calculated positions with a common fixed isotropic thermal parameter.
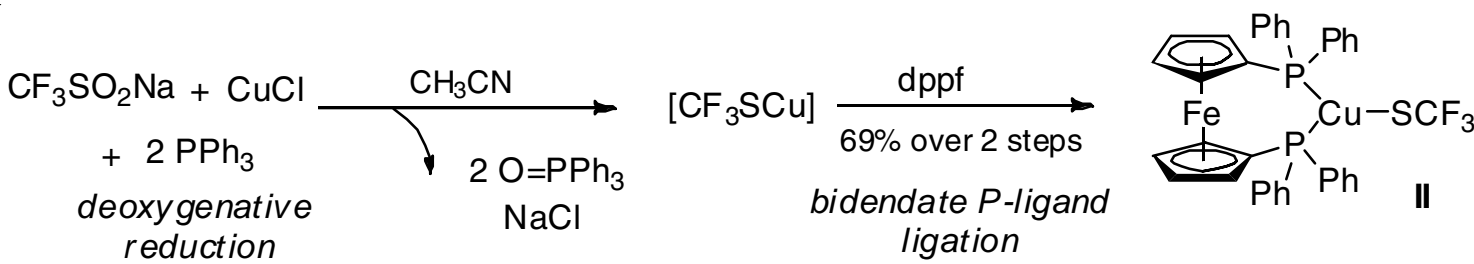

Scheme-I: Synthetic route of $\left[(\mathrm{dppf}) \mathrm{Cu}\left(\mathrm{SCF}_{3}\right)\right]$ complex II 


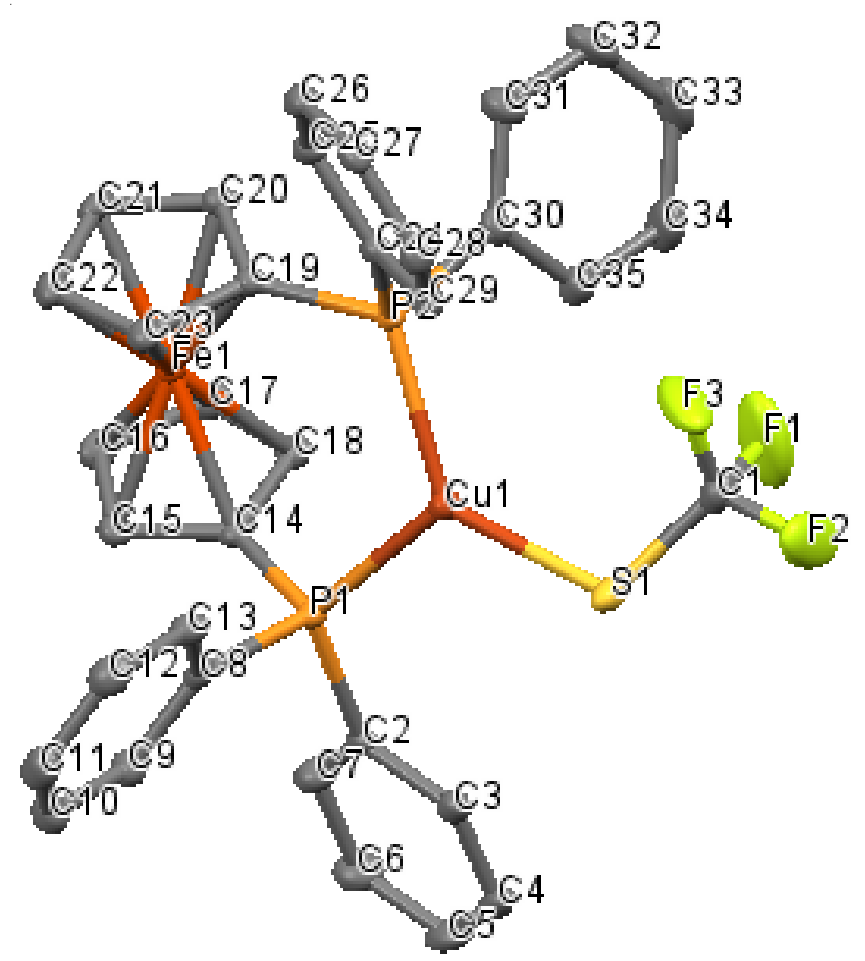

Fig. 2. ORTEP view of compound II (hydrogen atoms were omitted for clarity)

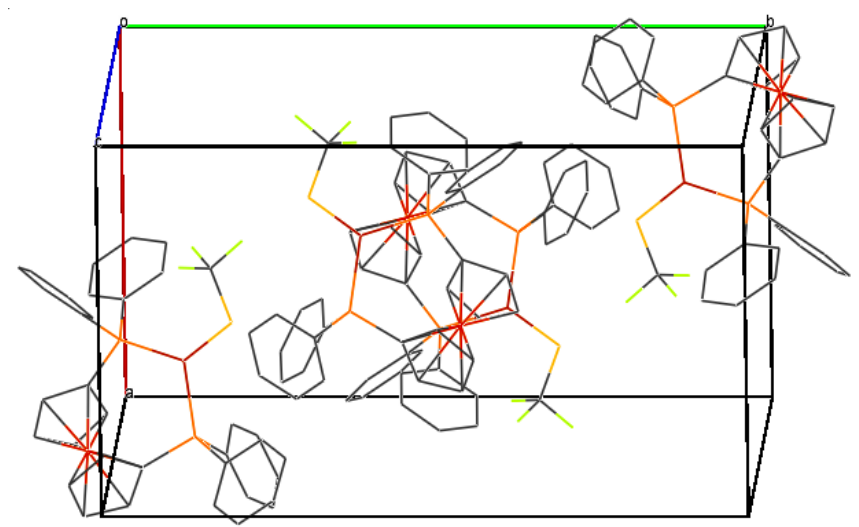

Fig. 3. Crystal packing diagram (wireframe) of compound (II) (hydrogen atoms were omitted for clarity)

\begin{tabular}{|c|c|}
\hline \multicolumn{2}{|c|}{$\begin{array}{l}\text { TABLE-1 } \\
\text { CRYSTAL DATA AND STRUCTURAL } \\
\text { REFINEMENT FOR COMPOUND (II) }\end{array}$} \\
\hline Items & Values \\
\hline Empirical formula & $\mathrm{C}_{35} \mathrm{H}_{28} \mathrm{~F}_{3} \mathrm{P}_{2} \mathrm{SCuFe}$ \\
\hline Formula weight & 719.00 \\
\hline Crystal system & Monoclinic \\
\hline \multicolumn{2}{|l|}{ Unit cell dimensions } \\
\hline $\mathrm{a}(\AA)$ & $11.4366(9)$ \\
\hline $\mathrm{b}(\AA)$ & $19.1340(16)$ \\
\hline c $(\AA)$ & $14.0625(11)$ \\
\hline \multicolumn{2}{|l|}{ Unit cell angles $\left({ }^{\circ}\right)$} \\
\hline$\alpha$ & 90 \\
\hline$\beta$ & $93.148(2)$ \\
\hline$\gamma$ & 90 \\
\hline Volume $\left(\AA^{3}\right)$ & 3072.62 \\
\hline $\mathrm{Z}$ & 4 \\
\hline Space group & $\mathrm{P} 2{ }_{1} / \mathrm{n}$ \\
\hline
\end{tabular}

TABLE-2

SELECTED BOND LENGTHS (Å) FOR COMPOUND (II)

\begin{tabular}{cc|cc}
\hline Bond & $\begin{array}{c}\text { Bond } \\
\text { lengths }(\AA)\end{array}$ & Bond & $\begin{array}{c}\text { Bond } \\
\text { lengths }(\AA)\end{array}$ \\
\hline $\mathrm{Cu}(1)-\mathrm{S}(1)$ & $2.2091(7)$ & $\mathrm{P}(2)-\mathrm{C}(19)$ & $1.807(2)$ \\
$\mathrm{Cu}(1)-\mathrm{P}(1)$ & $2.2523(6)$ & $\mathrm{P}(2)-\mathrm{C}(24)$ & $1.825(2)$ \\
$\mathrm{Cu}(1)-\mathrm{P}(2)$ & $2.2469(7)$ & $\mathrm{P}(2)-\mathrm{C}(30)$ & $1.828(2)$ \\
$\mathrm{S}(1)-\mathrm{C}(1)$ & $1.751(2)$ & $\mathrm{F}(1)-\mathrm{C}(1)$ & $1.325(3)$ \\
$\mathrm{P}(1)-\mathrm{C}(2)$ & $1.822(2)$ & $\mathrm{F}(2)-\mathrm{C}(1)$ & $1.330(3)$ \\
$\mathrm{P}(1)-\mathrm{C}(8)$ & $1.826(2)$ & $\mathrm{F}(3)-\mathrm{C}(1)$ & $1.327(3)$ \\
$\mathrm{P}(1)-\mathrm{C}(14)$ & $1.798(2)$ & - & - \\
\hline
\end{tabular}

TABLE-3

SELECTED BOND ANGLES $\left(^{\circ}\right)$ FOR COMPOUND (II)

\begin{tabular}{lc|lc}
\hline \multicolumn{1}{c|}{ Bond } & $\begin{array}{c}\text { Bond } \\
\text { angles }\left(^{\circ}\right)\end{array}$ & \multicolumn{1}{c}{ Bond } & $\begin{array}{c}\text { Bond } \\
\text { angles }\left(^{\circ}\right)\end{array}$ \\
\hline $\mathrm{S}(1)-\mathrm{Cu}(1)-\mathrm{P}(1)$ & $115.51(2)$ & $\mathrm{Cu}(1)-\mathrm{P}(2)-\mathrm{C}(30)$ & $109.02(7)$ \\
$\mathrm{S}(1)-\mathrm{Cu}(1)-\mathrm{P}(2)$ & $131.86(2)$ & $\mathrm{S}(1)-\mathrm{C}(1)-\mathrm{F}(1)$ & $114.6(2)$ \\
$\mathrm{P}(1)-\mathrm{Cu}(1)-\mathrm{P}(2)$ & $112.11(2)$ & $\mathrm{S}(1)-\mathrm{C}(1)-\mathrm{F}(2)$ & $112.4(2)$ \\
$\mathrm{Cu}(1)-\mathrm{S}(1)-\mathrm{C}(1)$ & $110.56(8)$ & $\mathrm{S}(1)-\mathrm{C}(1)-\mathrm{F}(3)$ & $115.3(2)$ \\
$\mathrm{Cu}(1)-\mathrm{P}(1)-\mathrm{C}(2)$ & $117.91(7)$ & $\mathrm{F}(1)-\mathrm{C}(1)-\mathrm{F}(2)$ & $103.5(2)$ \\
$\mathrm{Cu}(1)-\mathrm{P}(1)-\mathrm{C}(8)$ & $113.43(7)$ & $\mathrm{F}(1)-\mathrm{C}(1)-\mathrm{F}(3)$ & $104.1(2)$ \\
$\mathrm{Cu}(1)-\mathrm{P}(2)-\mathrm{C}(19)$ & $115.83(7)$ & $\mathrm{F}(2)-\mathrm{C}(1)-\mathrm{F}(3)$ & $105.9(2)$ \\
$\mathrm{Cu}(1)-\mathrm{P}(2)-\mathrm{C}(24)$ & $118.83(7)$ & - & - \\
\hline
\end{tabular}

With the X-ray crystal structure of $\left[(\mathrm{dppf}) \mathrm{Cu}\left(\mathrm{SCF}_{3}\right)\right]$ complex established, we commenced the comparative structural analysis between [(dppf) $\left.\mathrm{Cu}\left(\mathrm{SCF}_{3}\right)\right]$ and the sibling $\left[\left(\mathrm{Ph}_{3} \mathrm{P}\right)_{2} \mathrm{Cu}\left(\mathrm{SCF}_{3}\right)\right]$ derived from the supporting of monodentate triphenylphosphine ligand. It was found that both of $\left[(\mathrm{dppf}) \mathrm{Cu}\left(\mathrm{SCF}_{3}\right)\right]$ and $\left[\left(\mathrm{Ph}_{3} \mathrm{P}\right)_{2} \mathrm{Cu}\left(\mathrm{SCF}_{3}\right)\right]$ belonged to monoclinic crystal system with the space group of $\mathrm{P}{ }_{1} / \mathrm{n}$ and $\mathrm{Z}=4$. The bond lengths of $\mathrm{Cu}(1)$ $\mathrm{S}(1), \mathrm{Cu}(1)-\mathrm{P}(1), \mathrm{Cu}(1)-\mathrm{P}(2), \mathrm{S}(1)-\mathrm{C}(1), \mathrm{F}(1)-\mathrm{C}(1), \mathrm{F}(2)-\mathrm{C}(1)$, $\mathrm{F}(3)-\mathrm{C}(1)$ in the $\left[\left(\mathrm{Ph}_{3} \mathrm{P}\right)_{2} \mathrm{Cu}\left(\mathrm{SCF}_{3}\right)\right]$ crystal were also very similar to those of $\left[(\mathrm{dppf}) \mathrm{Cu}\left(\mathrm{SCF}_{3}\right)\right]$. Interestingly, the bond angles of $\mathrm{F}(1)-\mathrm{C}(1)-\mathrm{F}(2)\left\{\left[\left(\mathrm{Ph}_{3} \mathrm{P}\right)_{2} \mathrm{Cu}\left(\mathrm{SCF}_{3}\right)\right] 101.0(4)^{\circ} v\right.$. $\left.\left[(\mathrm{dppf}) \mathrm{Cu}\left(\mathrm{SCF}_{3}\right)\right] 103.5(2)^{\circ}\right\}, \mathrm{F}(1)-\mathrm{C}(1)-\mathrm{F}(3)\left\{101.6(4)^{\circ} v s\right.$. $\left.104.1(2)^{\circ}\right\}$ and $\mathrm{F}(2)-\mathrm{C}(1)-\mathrm{F}(3)\left\{108.5(4)^{\circ} v s .105 .9(2)^{\circ}\right\}$ displayed obvious differences that might be ascribed to the distinct steric compulsion of the phenyl groups on the supporting ligands.

Further interrogations on the subtle structural features within the crystal lattices between these two analogous crystals were conducted (Fig. 4). The short contacts between the two fluorine atoms $\{\mathrm{F}(1), \mathrm{F}(2)\}$ of $\mathrm{CF}_{3} \mathrm{~S}$ moiety and aromatic hydrogen of $\mathrm{Cp} /$ $(\mathrm{Ph})$ rings were observed in the crystal lattice of $\left[(\mathrm{dppf}) \mathrm{Cu}\left(\mathrm{SCF}_{3}\right)\right]$ with leaving the sterically-congested fluorine $\mathrm{F}(3)$ untouched. The contact distances of $\mathrm{F}(1) \cdots \mathrm{H} 34$ (A) (H on the Ph ring) and $\mathrm{F}(2) \cdots \mathrm{H}(21)(\mathrm{A})(\mathrm{H}$ on the $\mathrm{Cp}$ ring) were $2.533 \AA$ and $2.475 \AA$. On the other hand, the contact distances of $\mathrm{F}(1) \cdots \mathrm{H}(36)$ and $\mathrm{F}(3) \cdots \mathrm{H}(28)$ in the $\left[\left(\mathrm{Ph}_{3} \mathrm{P}\right)_{2} \mathrm{Cu}\left(\mathrm{SCF}_{3}\right)\right]$ were $2.556 \AA$ and 2.597 $\AA$, with leaving $\mathrm{F}(2)$ atom untouched. Evidently, the short interaction between $\mathrm{F}(2)$ and $\mathrm{H}(21)(\mathrm{A})$ of cyclopentadienyl ring was remarkably stronger than the other F...H contacts involving the hydrogen on the benzene ring. This phenomenon might be explained by the stronger electrostatic force between the fluorine and the more electron-positive hydrogen on the cyclopentadienyl ring which was heavily influenced by the divalent iron core (oxidation number +2 ). Additionally, the $\mathrm{S}(1)$ and $\mathrm{H} 5(\mathrm{~A})$ atoms formed short contact in the distance of $2.937 \AA$ within the crystal lattice of $\left[(\mathrm{dppf}) \mathrm{Cu}\left(\mathrm{SCF}_{3}\right)\right]$ while the similar $\mathrm{S} \cdots \mathrm{H}$ contacts were not observed in $\left[\left(\mathrm{Ph}_{3} \mathrm{P}\right)_{2} \mathrm{Cu}\left(\mathrm{SCF}_{3}\right)\right]$. 

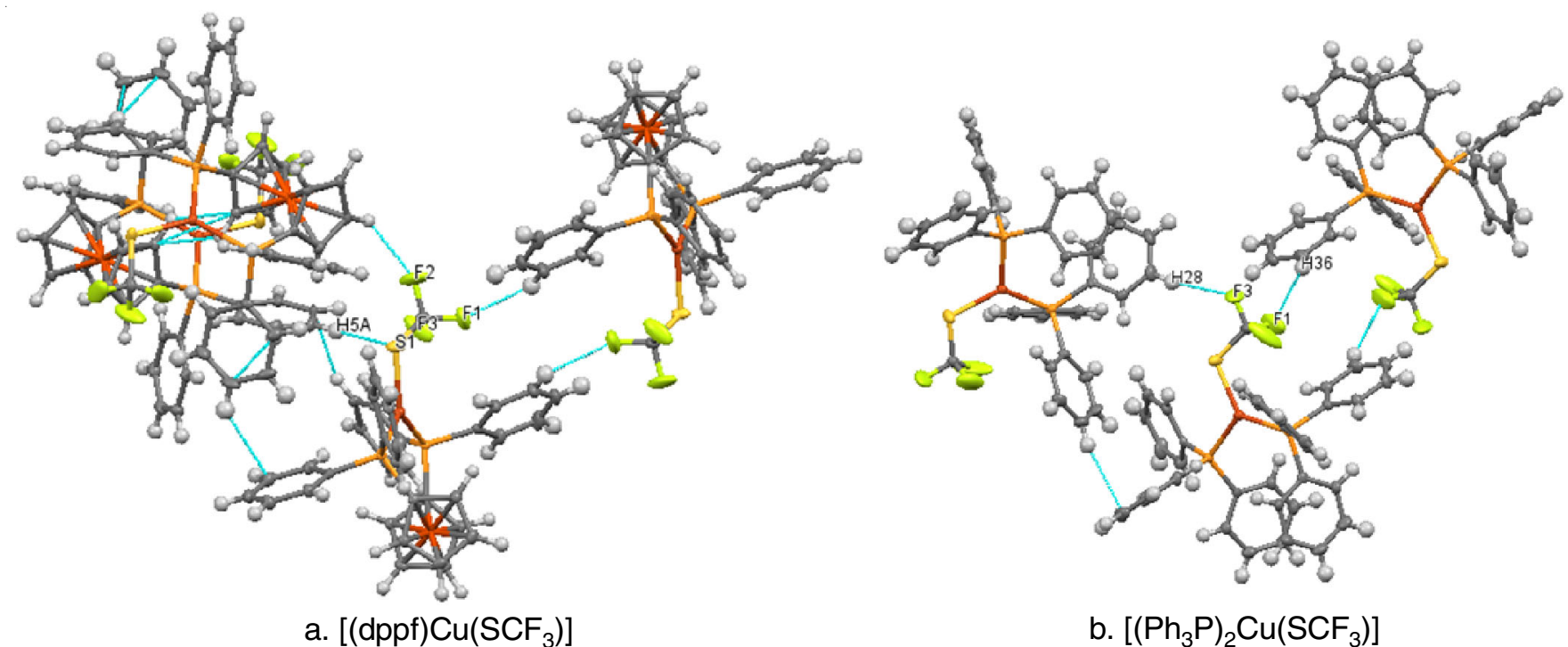

Fig. 4. Comparative analysis of the short intermolecular contacts between $\left[(\mathrm{dppf}) \mathrm{CuSCF}_{3}\right]$ and $\left[\left(\mathrm{Ph}_{3} \mathrm{P}\right)_{2} \mathrm{CuSCF}_{3}\right]$

\section{Conclusion}

In conclusion, we have disclosed the novel synthesis of $\left[(\mathrm{dppf}) \mathrm{Cu}\left(\mathrm{SCF}_{3}\right)\right]$ complex from the easily accessible $\mathrm{CF}_{3} \mathrm{SO}_{2} \mathrm{Na}$ via deoxygenative reduction and dppf coordination. The $\mathrm{X}$-ray crystal structure comparison between $\left[(\mathrm{dppf}) \mathrm{Cu}\left(\mathrm{SCF}_{3}\right)\right]$ and the sibling $\left[\left(\mathrm{Ph}_{3} \mathrm{P}\right)_{2} \mathrm{Cu}\left(\mathrm{SCF}_{3}\right)\right]$ demonstrated that both of them belonged to the same crystal system and space group. Moreover, these two copper trifluoromethylthiolate complexes displayed the similar F $\cdots \mathrm{H}$ short contacts in the crystal lattices with employing two fluorine atoms and leaving one fluorine atoms alone. The major structural difference between $\left[(\mathrm{dppf}) \mathrm{Cu}\left(\mathrm{SCF}_{3}\right)\right]$ and $\left[\left(\mathrm{Ph}_{3} \mathrm{P}\right)_{2} \mathrm{Cu}\left(\mathrm{SCF}_{3}\right)\right]$ lied in the bond angles of the trifluoromethyl motifs. We believe that the above structural information would be useful for the further exploration of $\left[\mathrm{L}_{\mathrm{n}} \mathrm{Cu}\left(\mathrm{SCF}_{3}\right)\right]$ complexes with refined ligands and tailored activities. Further studies of these $\left[\mathrm{L}_{n} \mathrm{Cu}\left(\mathrm{SCF}_{3}\right)\right]$ complexes as direct trifluoromethylthiolation reagents for novel reaction developments are underway and the results will be reported in due course.

Supplementary data L: CCDC-1401244 contains the supplementary crystallographic data of $\left[(\mathrm{dppf}) \mathrm{Cu}\left(\mathrm{SCF}_{3}\right)\right]$ for this paper. These data can be obtained free of charge via http:/ /www.ccdc.cam.ac.uk/conts/retrieving.htmL, or from the Cambridge Crystallographic Data Centre, 12 Union Road Cambridge CB2 1EZ, UK (Fax: +44-1223-336033; or E-mail: deposit@ccdc.cam.ac.uk $)$. The elemental analysis and ${ }^{1} \mathrm{H}\left({ }^{13} \mathrm{C}\right.$, ${ }^{19} \mathrm{~F},{ }^{31} \mathrm{P}$ ) NMR characterization data can be found in the supplementary materials of this literature (Chem. Eur. J., 22, 858 (2016)).

\section{ACKNOWLEDGEMENTS}

The authors thank National Natural Science Foundation of China (21502131), Science \& Technology Department of Sichuan Province (2018JZ0061, 2018HH0128), Education Department of Sichuan Province (18CZ0024), Key Laboratory of Vanadium and Titanium of Sichuan Province (2018FTSZ03), Sichuan University of Science and Engineering (2017RCL03) and Sichuan Youth Plan for financial support.

\section{CONFLICT OF INTEREST}

The authors declare that there is no conflict of interests regarding the publication of this article.

\section{REFERENCES}

1. S. Barata-Vallejo and A. Postigo, Coord. Chem. Rev., 257, 3051 (2013); https://doi.org/10.1016/j.ccr.2013.07.004.

2. H. Wang and D.A. Vicic, Synlett, 24, 1887 (2013); https://doi.org/10.1055/s-0033-1339435.

3. X.-H. Xu, K. Matsuzaki and N. Shibata, Chem. Rev., 115, 731 (2015); https://doi.org/10.1021/cr500193b.

4. L. Chu and F.-L. Qing, Acc. Chem. Res., 47, 1513 (2014); https://doi.org/10.1021/ar4003202.

5. K. Zhang, X.-H. Xu and F. Qing, Youji Huaxue, 35, 556 (2015); https://doi.org/10.6023/cjoc201501017.

6. Z. Weng, W. He, C. Chen, R. Lee, D. Tan, Z. Lai, D. Kong, Y. Yuan and K.-W. Huang, Angew. Chem. Int. Ed., 52, 1548 (2013); https://doi.org/10.1002/anie.201208432.

7. D. Kong, Z. Jiang, S. Xin, Z. Bai, Y. Yuan and Z. Weng, Tetrahedron, 69, 6046 (2013);

https://doi.org/10.1016/j.tet.2013.05.073.

8. J. Tan, G. Zhang, Y. Ou, Y. Yuan and Z. Weng, Chin. J. Chem., 31, 921 (2013);

https://doi.org/10.1002/cjoc.201300415.

9. Z. Wang, Q. Tu and Z. Weng, J. Organomet. Chem., 751, 830 (2014); https://doi.org/10.1016/j.jorganchem.2013.08.008.

10. Y. Huang, J. Ding, C. Wu, H. Zheng and Z. Weng, J. Org. Chem., 80, $2912(2015)$ https://doi.org/10.1021/acs.joc.5b00144.

11. Y. Yang, L. Xu, S. Yu, X. Liu, Y. Zhang and D.A. Vicic, Chem. Eur. J., 22, 858 (2016); https://doi.org/10.1002/chem.201504790.

12. J.H. Clark, C.W. Jones, A.P. Kybett, M.A. McClinton, J.M. Miller, D. Bishop and R.J. Blade, J. Fluor. Chem., 48, 249 (1990); https://doi.org/10.1016/S0022-1139(00)80437-6.

13. J.H. Clark and H. Smith, J. Fluor. Chem., 61, 223 (1993); https://doi.org/10.1016/S0022-1139(00)80106-2.

14. Crystal Clear and Crystal Structure, Rigaku and Rigaku Americas 9009 New Trails Dr. The Woodlands TX 77381 USA.

15. G.M. Sheldrick, SHELXS97, A Program for Crystal Structure Solution, University of Göttingen: Germany (1997).

16. G.M. Sheldrick, SHELXS97, A Program for Crystal Structure Refinement, University of Göttingen: Germany (1997).

17. L. Jiang, J. Qian, W. Yi, G. Lu, C. Cai and W. Zhang, Angew. Chem. Int. Ed., 54, 14965 (2015);

https://doi.org/10.1002/anie.201508495. 